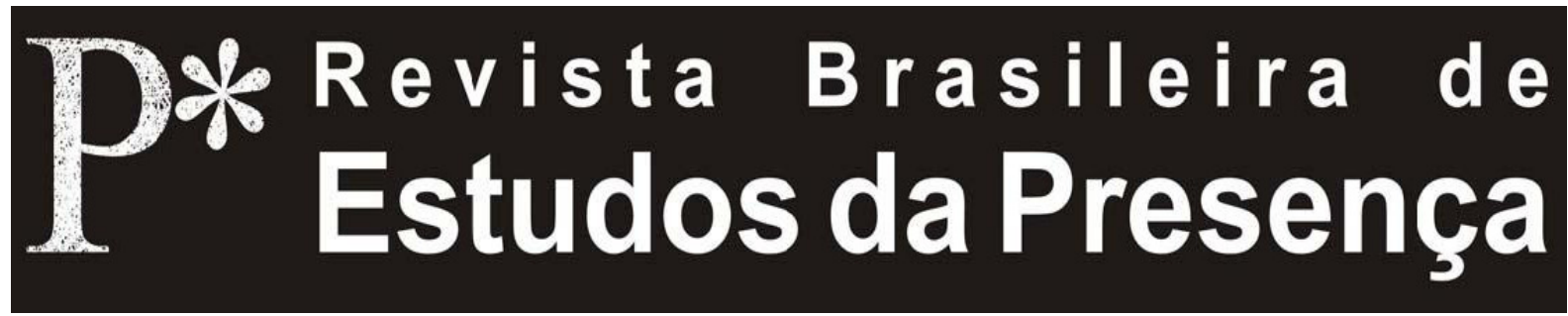

DOI - http://dx.doi.org/10.1590/2237-266033249

ISSN 2237-2660

\title{
O Século de Jerzy Grotowski
}

\author{
Antonio Attisani \\ Università di Torino - Torino, Itália
}

RESUMO - O Século de Jerzy Grotowski ${ }^{1}$ - Segundo o autor, no século XXI se descobrirá a importância fundamental da investigação realizada pelo mestre polonês e, sobretudo através da mediação do Workcenter of Jerzy Grotowski and Thomas Richards, se poderá aproveitar os resultados artísticos daquela história e uma concepção da práxis dos atores e dos diretores livre de preconceitos ideológicos e morais, de modo que o legado grotowskiano seja um dos fundamentos de uma cultura teatral nova, baseada na presença e no encontro. Palavras-chave: Jerzy Grotowski. Workcenter of Jerzy Grotowski and Thomas Richards. Ator. Herança de Stanislavski. Teatro Contemporâneo.

ABSTRACT - The Century of Jerzy Grotowski - According to the author, in the twentyfirst century there will be a discovery of the importance of the Polish master's research and - especially through the mediation of the Workcenter of Jerzy Grotowski and Thomas Richards - it will be possible to use the results of the history and a conception of actors's and directors's praxis free from ideological and moral prejudices, so that Grotowski's legacy will be one of the foundations of a new theatrical culture, based on presence and encounter. Keywords: Jerzy Grotowski. Workcenter of Jerzy Grotowski and Thomas Richards. Actor. Stanislavski's Legacy. Contemporary Theatre.

RÉSUMÉ - Le Siècle de Jerzy Grotowski - D'après l'auteur, c'est au XXIème siècle que l'on découvre l'importance majeure de la recherche menée par le maître polonais, grâce notamment à la médiation du Workcenter ofJerzy Grotowski et Thomas Richards. Médiation qui a permis de diffuser les résultats artistiques de cette recherche, ainsi qu'une conception de la praxis des acteurs et metteurs en scène libre de tout préjugé idéologique et moral, faisant de l'héritage de Grotowski le socle d'une culture théâtrale nouvelle, fondée sur la présence et la rencontre.

Mots-clés: Jerzy Grotowski. Workcenter of Jerzy Grotowski and Thomas Richards. Acteur. Héritage de Stanislavski. Théâtre Contemporain. 
Em 2009, no Ano de Grotowski, proclamado pela Unesco, foi proposto um apaixonado desfile de recordaçóes que lançaram uma nova luz sobre a obra do mestre polonês, sobre sua recepçáo nas décadas passadas e sobre sua contínua atualidade. Na mesma ocasião, porém, assistiu-se a autocelebração de muitos veteranos do grotowskismo e a autopromoçáo de novos grotowskianos que oferecem ao mercado do bem estar espiritual e da arte teatral uma improvável marca e métodos garantidos pelo seu nome. Agora, terminadas as celebraçóes, poder-se-á retomar, espera-se, o século de Grotowski, ou seja, o verdadeiro trabalho para restaurar e entregar sua obra aos jovens do século XXI, que a visitaráo fora dos circuitos institucionais e a utilizarão sem escrúpulos, como já aconteceu no século passado com o Zarathustra de Nietzsche e os escritos de Antonin Artaud.

Para delinear a consistência desse legado e os nossos objetivos, pode-se fazer referência, antes de tudo, à autoridade indiscutível de Peter Brook. O diretor anglo-francês é para o público do teatro um pouco como o Dalai Lama é para os tibetanos: todos o amam e o respeitam, todos, ou quase todos, reconhecem que ele soube como poucos definir de maneira tangível a missão do teatro no nosso tempo. Brook disse: "O trabalho de Grotowski é único, o que ele deixou é um tesouro, e como todo tesouro deve ser amado, respeitado e tratado com muito, muito cuidado". Em seu discurso inaugural do Ano de Grotowski, Brook propôs três questôes fundamentais: a importância e a atualidade de Grotowski, a verificação da consistência deste tesouro, bem como maneiras para conservá-lo e utilizá-lo e a indicação do Workcenter de Jerzy Grotowski e Thomas Richards como seu principal depositário ${ }^{2}$. O fato de que ninguém o tenha publicamente contradito não significa que exista um acordo unânime sobre o que é amar, respeitar e tratar com muito cuidado o patrimônio que Grotowski nos deixou. O que Brook disse era, mais do que tudo, um presságio, provavelmente formulado, com a delicadeza que o diferencia, pensando exatamente na situação bem diferente que o panorama das celebraçóes manifestou pontualmente: de fato, assim como a maioria dos que dizem admirar e respeitar o Dalai Lama ambicionam, principalmente, ser fotografados ao lado dele para valer-se disso como um simulacro e publicidade, mas, na realidade, evitam empenhar-se na difícil causa tibetana, os clérigos do grotowskismo colocaram em primeiro plano, sobretudo, a si mesmos, deixando de se confrontar com as perguntas e as estratégias 
propostas pelo diretor polonês para evitar "uma vida de merda"3 (Vassiliev, 2008, p. 76). Amar Grotowski, ou seja, levá-lo seriamente em consideração, significa submeter-se a um trabalho exigente, com o tempo recompensador, mas de imediato muito cansativo e seletivo, porque Grotowski não é nem um pouco conciliador com a mediocridade cultural do nosso tempo.

Uma primeira questão, então: para compreender a importância e a atualidade de Grotowski, é necessário, antes de tudo, ler atentamente os seus textos. Por exemplo, hoje em todo o mundo são muitos aqueles que dizem conhecer Em busca de um teatro pobre e os outros numerosos e importantes escritos de Grotowski, mas, de fato, muito poucos os leram como se deveria; isso porque a superficialidade, junto à liberdade de mentir, constitui uma das epidemias do nosso tempo, ou talvez porque ainda não dispomos de traduções e edições adequadas ${ }^{4}$. Todos aqueles aos quais esse problema concerne deveriam fazer algo de concreto na sua própria língua; para restaurar ediçóes filologicamente corretas daqueles textos e depois preparar aparatos críticos adequados. Ao lê-los, será necessário distinguir entre a sua essência e os aspectos ligados às circunstâncias sociais e culturais nas quais surgiram; em certo sentido, é necessário proceder como Aristóteles prescrevia aos autores das tragédias. Uma vez focalizada essa essência, isto é, os novos princípios que marcam na história do teatro muitos outros pontos de não retorno, precisa-se assumir uma responsabilidade que ninguém pode ensinar a outra pessoa, aquela de recontextualizá-los no próprio presente. Não se trata de adaptá-los, aqueles princípios, mas, ao contrário, de aceitar o desafio proposto pela sua radicalidade, encontrando na própria vida e profissão os pontos de apoio correspondentes e reconhecendo com precisão os inimigos, ou seja, as concepçóes contra as quais lutar, os equívocos ou os compromissos a serem evitados. Tudo isso porque Grotowski apresenta o problema do sentido do teatro na sociedade do espetáculo e, através de uma disciplinada práxis experimental, formula uma resposta ainda atual, demonstrando que não é inevitável fazer parte da sociedade do espetáculo e, tampouco, consumir-se em uma crítica interna a ela (que enfim é a mesma coisa), e que, em vez disso, é possível, com o teatro, praticar o caminho da arte. A criatividade, unida a um rigor dos protocolos técnicos, também restitui à arte uma dignidade ética e um rigor científico. 
Procurei demonstrar - não sei se com sucesso - que quando Grotowski afirma que "a técnica está na realização"s (Grotowski, 2001, p. 48) se relaciona de fato a uma tradição artística e filosófica do Século XX ainda não adequadamente reconhecida, que nasce de um confronto da cultura ocidental com os próprios fundamentos (definidos por Grotowski como o berço) e com as tradiçóes de outras civilizações. Uma de nossas tarefas é, portanto, a de reconstruir a genealogia desta concepção da mimesis sob o plano teórico e histórico, conectando, por exemplo, a sua instância com o pensamento do último Gilles Deleuze, aquele que ressalta a importância do acte de création, o autor de textos decisivos neste sentido como $O$ ato de criação (1987), Crítica e clínica (1993) e A imanência: uma vida... (1994). Uma proposta análoga é apresentada por Carlo Sini, o qual nos recorda a raiz comum da arte, rito e ritmo e a concepção das artes dinâmicas como uma unidade originária da música, poesia e dança, lugar da mousiké em ação e, consequentemente, também fundamental instrumento de educaçãó ${ }^{6}$. Desse modo, a questão do poder a combater e aquele a conquistar assume um aspecto significativamente diferente tanto da perspectiva capitalista desumanizada, quanto daquelas marxista e pós-marxista consideradas canônicas. Antes da época em que vivemos, a arte e a técnica coincidiam, antes de ser ars a arte era techne. Quando Grotowski afirma que a técnica está incluída na realizaçáo e não equivale à preparação, de fato, convida a reconquistar tal coincidência. Neste sentido, a ajuda que pode vir de algumas culturas antigas tem que ser temperada por uma consciência realmente diferente do mundo no qual vivemos e no qual o ressurgimento só pode assumir um aspecto inédito. Isso significa que uma estratégia criativa não é algo que se possa restaurar, mas é para ser inventada ex novo, todos os dias e nas circunstâncias particulares de cada vida.

O tesouro que Grotowski deixou é composto pelos seus escritos, mas também por um registro audiovisual integral das três obras mais importantes criadas por ele (agora, finalmente todas foram restauradas: Akropolis, o Principe constante e Apocalypsis cum figuris) e por muitas entrevistas, conferências e depoimentos sobre vários aspectos do trabalho desenvolvido pelo Teatr Laboratorium. Mas, nessa mesma perspectiva, é necessário considerar também o Workcenter, na verdade sua obra principal, e viva, à qual, ao longo do texto, serão dedicadas 
algumas reflexôes. Sobre o modo de conservá-lo já foi dito alguma coisa, agora talvez seja necessário acrescentar algumas consideraçóes sobre como utilizá-lo, ou ainda, sobre como nós, que somos os leitores desses documentos, nós que não fomos testemunhas diretas daquela época ou ainda seus alunos, nós que trabalhamos nos mais variados contextos e náo estamos simplesmente interessados em saber como foram as coisas; devemos, ou gostaríamos de, compreender de que maneira uma experiência do passado pode enriquecer o nosso trabalho no presente.

Certamente não estamos negligenciando a dimensão histórica e filológica do tema, sobre a qual já existem muitas páginas, ainda que nem todas competentes. Quando uma das mais importantes testemunhas do curto século teatral, como Ludwik Flaszen, descreve uma Polônia caracterizada por uma "[...] relação, sem dúvida complexa, ambígua, paradoxal ou, mais simplesmente, perversa, entre a liberdade e a restrição, entre o impulso criativo e as trevas da criação" 7 (Flaszen, 2007, p. 41), evoca diversos elementos de uma antropologia cultural única no mundo, caracterizada pelo autoritarismo da igreja comunista e da igreja católica em competição entre elas pelo domínio dos corpos e das mentes, mas, apresenta também o papel fundamental da peculiar tradição romântica polonesa e a influência da sensibilidade judaica e do hassidismo (traços fisicamente, mas, não idealmente, apagados pelo nazismo e depois pelo comunismo), e, portanto, fala da singularidade de uma opressão da qual, para fugir, os intelectuais mais dotados e corajosos utilizavam referências pouco conhecidas, se não estranhas ao resto do mundo. Somente à luz dessa contradição se explica como um país de segunda importância no setor geopolítico contemporâneo conseguiu gerar tantas figuras de primeiro nível em todos os setores artísticos e do pensamento. E somente desse modo pode-se compreender o emergir no horizonte do teatro de duas figuras importantes como Tadeusz Kantor e Jerzy Grotowski, muito menos distantes entre si do que se crê, destinadas a permanecer atuais em um mundo que, com sempre maior determinação, ainda está procurando um terceiro caminho entre o integralismo materialista e o integralismo espiritual, cuja contraposição arrisca precipitar a noção mesma de humano em um abismo sem fundo.

Tudo isso levou não só a uma seleção implacável de talentos, mas, também a uma investigação artística complexa e variada, em 
relação a qual se está delineando a hipótese de um grotesco que, por exemplo, une as figuras de Grotowski e Kantor, mais uma vez desmentido ou reformulado os motivos de contraposição apresentados pelo senso comum. Esta sensibilidade grotesca e metafórica deve muito, como já foi dito, a algumas correntes do judaísmo (pensemos, por exemplo, na relação de Grotowski com o hassidismo e naquela de Kantor com um autor como Bruno Schulz). Essa instância grotesca na qual a vida, os corpos e as formas entendidas como lugar e tempo de convivência de opostos irredutíveis, se opóe às simplificaçóes do realismo e, no caso polonês, se relaciona, sobretudo à causa da ascendência hassídica, a uma particular inclinação em direção ao êxtase e à ironia, ao canto e à dança, enfim, à alegria e à vida plena do artesão-criador.

Isso para dizer que um resgate histórico-filológico deveria servir também para examinar as obras específicas e trazer para o primeiro plano aqueles elementos da poética que se revelam atuais, exatamente porque remetem a problemas ainda sem solução e à inventividade com a qual foram enfrentados. O teatro polonês do segundo pós-guerra não espera nem uma exegese passiva, nem uma crítica ideológica, mas uma obra de desconstrução e uma observação das suas estratégias miméticas que coloque em destaque a essência de um jogo inflexível, conduzido por aqueles criadores que concebiam a arte como luta e como construçáo de um espelho que, diferentemente dos vários realismos, refletisse uma realidade não oficialmente visivel, colocando perguntas mais substanciais.

A este respeito, pode-se acrescentar também que as filmagens das três obras citadas poderiam permitir algumas descobertas úteis. Por exemplo, Apocalypsis cum figuris, filmado pelo grande diretor que é Ermanno Olmi, não se pode considerar um filme perfeitamente bem sucedido (como é muito discutível a única filmagem integral da Classe morta de Kantor realizada por Andrzej Wajda), porém, é de grande importância revê-lo hoje, porque se pode colher o conteúdo mais profundo: de fato, além dos traços estilísticos que naquela época o conotava como uma obra marcadamente polonesa, Apocalypsis aparece como uma alegoria da revolta e das esperanças das quais eram portadores, em todo o mundo, os jovens dos anos 1960, incluindo suas ambiguidades e a falta de sólidas referências que permitiram ao poder capitalista atualizar-se em alguns aspectos e retomar as rédeas da sociedade. 
Como se vê, o trabalho a ser desenvolvido no século de Grotowski não é puramente acadêmico e requer um considerável empenho. Ao mesmo tempo, parece compreender que o tesouro do qual fala Brook poderia ser uma contribuição decisiva para a cultura teatral do futuro.

Passemos agora ao Workcenter of Jerzy Grotowski and Thomas Richards, o principal sucessor da nova tradição marcada pelo eixo Stanislavskij-Grotowski. Gostaria de ressaltar somente alguns aspectos, sempre dentro do quadro do princípio geral segundo o qual é interessante, e mesmo decisivo, ler Grotowski olhando para o Workcenter e vice versa.

Os dois atuais líderes do Workcenter, Thomas Richards e Mario Biagini, são atores aos quais Grotowski dedicou os últimos treze anos da própria vida, nomeando-os seus herdeiros. Sáo seus discípulos de diferentes modos. Esses atores são, a meu ver, performers, com $\mathrm{p}$ minúsculo, como autores completos da criação teatral, (enquanto Grotowski era, essencialmente, um diretor) mas, também podem ser colocados na perspectiva do Performer, com P maiúsculo, ou seja, a figura que Grotowski propóe como um ideal em seu único escrito que não se refere a uma experiência passada ${ }^{8}$.

Já se passaram mais de dez anos da morte de Grotowski e o mundo está percebendo que o Workcenter desenvolve aquela herança. Tudo isso é provado, felizmente, por uma série de escritos e de material audiovisual que documentam as diversas fases do trabalho, que teve início com o próprio Grotowski9.

Atualmente, Richards e Biagini desenvolvem, ambos, sua própria atividade, em duas áreas, no entanto, seguindo cada um sua própria direção. Simplificando, somos tentados a dizer que Richards se concentra na arte como veículo e sobre o processo; enquanto Biagini parece estar mais orientado para a composição de obras performativas que se movam ao encontro com os espectadores. Isso é correto, mas não totalmente exato. Mais exato seria reconhecer que Biagini privilegia um procedimento informal, ou seja, a composição de formas e a sua montagem, enquanto Richards tende preferencialmente para a conquista e a expressáo do polo interior e mais secreto dos fenômenos inter-humanos. Sáo dois modos complementares de conectar vida e formas.

Os espetáculos que os dois oferecem são muito interessantes se considerados, por exemplo, à luz do último ensaio de Grotowski, Da companhia teatral à arte como veiculo $(1989-1995)^{10}$. Se Performer 
define um ideal ou um objetivo Da companhia..., sobretudo se for lido hoje, deixa entender que a passagem da arte como apresentaçáo à arte como veículo, náo deveria ser entendida como um ponto de chegada definitivo, mas como um passo ao lado, uma jogada de mestre, necessária a Grotowski e aos seus colaboradores para avançar em um determinado momento e em determinadas condiçóes e neste sentido deve ser considerada útil, desde que se traga o conceito para o próprio trabalho. Isso vale para qualquer pessoa que faça teatro. Este texto, porém, é frequentemente mal interpretado, porque é difícil compreender que a distinção está baseada no pressuposto de que, na realidade, a arte é um veículo, ou melhor, era, deveria sê-lo, e o será novamente, se formos capazes de reconquistar a sua funçáo de ato de conhecimento (de si) e, portanto, de transformaçáo individual e coletiva. Grotowski, como bem explicou Ludwik Flaszen ${ }^{11}$, estava em constante controvérsia com a linguagem e deve ser lido discernindo-se entre as contínuas mudanças da terminologia - relacionadas a uma incansável busca de precisão e à tentativa de não criar novos e insignificantes clichês - e a perseguição do objetivo ao qual dedicou toda a vida.

Para realizar esse objetivo, muito claro, contudo indizível, Grotowski desenvolveu uma sensibilidade biosófica, encontrando profunda relaçáo com os homens da ciência ou os expoentes de outras disciplinas muito mais que com os artistas. O estudo da natureza e da vida náo pode ser submetido a crenças ou dogmas e se concentra principalmente na técnica (que não é a mesma coisa que tecnologia). Por isso, a operação Grotowskiana e do Workcenter possui um caráter secular, totalmente sem preconceitos, e até mesmo o interesse por alguns grandes místicos deve ser compreendido neste contexto, no qual se vê a técnica como outro modo de conceber o teatro com relaçáo à ideologia e à economia, as duas divindades supremas do século XX. Esta nova (ou arcaica) comunhão entre arte e técnica é possível atualmente, desde que se reconheça que a dissociaçáo entre arte como apresentaçáo e arte como veículo, que caracteriza a nossa época, pode ser superada somente através de uma prática, não apenas de uma teoria, e de uma verificaçáo inflexível de ambos os aspectos.

O que me interessa ressaltar aqui é que o pragmatismo Grotowskiano, e hoje do Workcenter, representa o êxito mais alto e mais atual de uma revolução teatral que foi iniciada, pelo menos, com Stanislavski e pode ser sintetizada com base em palavras-chave como 
Companhia, Ator, Psicotécnica, Ioga e, enfim, Música. A companhia é o ambiente coletivo, a dimensão ética e política é a metonímia do social no trabalho da arte comum; o ator é a encarnaçáo do entrelaçamento entre arte, técnica e ética profissional; a psicotécnica deve ser entendida como um trabalho sobre si mesmo, mas também como estudo, aplicação e verificação das contínuas descobertas científicas, sobretudo daquelas relativas à unidade corpo-mente; o ioga (disciplina que cada um pode praticar encontrando o ramo adequado para si) deve ser entendido como filosofia prática, trabalho com o corpo e transcendência realizada. Enquanto Música é o nome que se dá ao lugar e ao modo da síntese teatral para indicar as suas raízes ${ }^{12}$.

Mas, sobretudo é bom enfatizar um aspecto que, se não esclarecido, pode gerar perigosos equívocos: a arte como veículo náo é algo que possa prescindir da arte, não se trata de uma espécie de animação ou de um ioga coletivo, de uma nova patente que permita conseguir, talvez rapidamente, um bem estar espiritual individual. Ao contrário: apenas a conquista e a superação de uma excelência artística podem levar àquela verticalidade ou higher connection que Grotowski indica como o objetivo supremo. É importante que todos, mas, especialmente, os mais jovens, compreendam isso. Grotowski era um admirador de Ramana Maharishi, o qual acreditava que para estabelecer e alcançar a meta basta fazer uma simples pergunta: Quem sou eu? (ou: $\mathrm{O}$ que sou eu?, ou, melhor ainda: O que é eu?). E entáo, no nosso mundo, quem experimenta o desejo da verticalidade poderia reformular a pergunta nesses termos: em qual arte posso alcançar e superar aquela excelência que permitirá tornar-me eu mesmo? (Porque está claro que a excelência é o ponto culminante do ego, o umbral além do qual começa "o meu homem" (Grotowski, 2007, p. 81), para usar as palavras de Grotowski).

Para confirmar que Grotowski não é o único nessa busca, podese fazer referência a algumas páginas esclarecedoras de René Daumal sobre Émile Jaques-Dalcroze ${ }^{13}$ (Daumal, 1972, p. 271), o criador da disciplina chamada euritmica. Jaques-Dalcroze, escreve Daumal na resenha de um sarau parisiense de exibiçóes, é movido pela intenção sacrossanta de "restituir à palavra 'compreender' o sentido de assunção em si mesmo de todos os aspectos da vida" (Daumal, 1972, p. 273). Para Dalcroze, a arte é um "meio" de escapar da "monstruosa anarquia” moderna das especializações e da dissociação das linguagens. Os seus dançarinos-musicistas, jamais mediocres e de um virtuosismo 
prodigioso, são a demonstração de que é possível uma qualidade de vida muito superior àquela que nos parece normal. Nós parecemos, diz, "[...] pessoas que esqueceram aquilo que procuram, seres miseráveis como gorilas enjaulados que passam horas e horas fazendo e desfazendo nós com fios de palha, como se esquecessem continuamente que esses fios poderiam servir para a construção de uma casa" (Daumal, 1972, p. 273). O projeto dalcroziano, portanto, é um projeto grandioso cuja realização parcial comprova, porém, uma falha substancial; de fato, os atores euritmicos, insiste Daumal, "[...] parece que podem fazer tudo: mas é preciso reconhecer que, na realidade, não sabem o que fazer" e "consciente ou inconscientemente, exercitam-se para imitar, com todo o seu corpo, seres humanos dotados daquele conhecimento", eles "parecem não possuir nada para expressar", não só ideias mas nem mesmo um "simples sentimento", e "[...] não demonstram nada além de sombras ou convençóes de sentimentos, atitudes vazias e já praticamente estereotipadas" (Daumal, 1972, p. 273). Sua extraordinária habilidade pode servir mais para criar um espetáculo de sucesso (o que, entre outras coisas, dizem náo querer) e pode contribuir para um certo conforto individual, mas estamos ainda a uma distância sideral, insiste Daumal, de uma "[...] arte feita para servir o ser humano e não para escravizá-lo, uma arte feita para o conhecimento e náo para o divertimento" (Daumal, 1972, p. 270). O erro básico dessa concepçáo de teatro e de arte deriva exatamente em dissociar o meio do fim, uma vez que Jaques-Dalcroze estava convencido de que seu ensinamento deveria limitar-se a preparar e depois cada um teria que ir atrás do próprio objetivo.

Os eurítmicos lembram, de fato, muitos grotowskianos em circulação. A principal diferença da qual Grotowski é portador, desde os tempos de Em busca de um teatro pobre, é, ao contrário, a concepçáo da "arte como meio" (Peter Brook no seu prefácio) (Brook, 1968, p. 11), ou seja: a técnica está na realização, não na preparação. Somente ao se compreender esta nuance decisiva, pode-se lidar seriamente com a arte como veículo.

Quando Daumal apresentava a questáo da arte naqueles termos, podia defini-la apenas, com um oxímoro, como metafísica experimen$\mathrm{tal}$, porque naquele momento tudo o que não era visível era relegado fatalmente ao sombrio reino da metafísica. Hoje, pelo contrário, a ciência permite-nos cada vez mais ver aquilo que antes era invisível, e o estudo do DNA demonstrou que a experiência artística pode 
constituir um aspecto importante da epigenética, uma atividade de regulação dos genes por meio de processos (químicos) que não envolvem mudanças no código genético, mas podem modificar o fenótipo do indivíduo, ou a efetiva, total manifestação física de um organismo (entendido como alternativa ao genótipo, ou seja, os caracteres hereditários, que podem ou não se manifestar). As descobertas permitem, portanto, repensar noçóes arcaicas sob uma nova luz. A arte objetiva com a qual G. I. Gurdjeff parecia divagar é, portanto, algo que existe desde tempos imemoriais, e o apocatástase que ocupa um lugar considerável na gnose - a saber, a transformação das energias negativas em positivas na perspectiva do retorno a si, a verdadeira ressurreição - pode ser invocado pelo poeta beat Allen Ginsberg como o equivalente contemporâneo da já desonrada revolução.

Se quisermos ser protagonistas e não apenas espectadores passivos da própria época é preciso tornarmo-nos atores criativos. Um ator criativo é também um espectador crítico, mas quem se limita a ser um espectador crítico é fadado ao fracasso quando passa à ação. Nós somos sortudos: vivemos um belo fim de século, se consideramos o apogeu da arte e do pensamento representado por figuras como Grotowski e Kantor, Carmelo Bene e Gilles Deleuze. Estáo todos mortos, mas deixaram vários tesouros da arte e do pensamento; a responsabilidade de compreender suas mensagens é só nossa. Não é por acaso, por exemplo, que Deleuze tenha se demitido apelando para o ato da criação, não a um sistema de pensamento, mas à prática da composição (para ele sinônimo de arte).

Para concluir de forma otimista, pode-se dizer algumas palavras sobre como o Workcenter está trabalhando para conservar e aumentar o tesouro deixado por Jerzy Grotowski. Acredito que aqueles que conheceram esta companhia cosmopolita em anos precedentes ficarão muito impressionados com as inovaçóes que estáo emergindo desse fluxo, inovaçóes substanciais, uma vez que não surgem de uma pesquisa de soluçôes formais, mas de processos que unem o conhecimento de si a uma visáo poética sobre o mundo de hoje.

Uma das coisas a se fazer é começar a distinguir o trabalho realizado pelos guias do Workcenter, Richards e Biagini. Por parte dos observadores, há ainda a tendência a falar deles como se fizessem coisas idênticas, mas os dois, como todos os seres humanos, são diferentes, diferentes foram suas relações com Grotowski e inclusive com o trabalho na sua totalidade. Portanto, dois destinos, no sentido 
de funções e tarefas: Richards é, de certo modo, o ovo que a galinha Grotowski dedicou-se a colocar, enquanto Biagini, discípulo náo menos importante se bem que de uma forma diferente, demonstra, há anos, concentrar-se sobre alguns elementos do ensinamento.

Desde o início de 2008, Richards começou a trabalhar com um novo grupo internacional de jovens atores. O trabalho do Focused Research Team in Art as Vehicle consiste em um processo de ensino através da criação. $\mathrm{O}$ grupo atua direcionando a atenção, ao mesmo tempo, ao crescimento interior e ao desenvolvimento das próprias competências como profissionais de teatro. Com base em antigos cantos provenientes das tradiçóes africana e afrocaribenha, e de textos que vão da tradição ocidental à dos Bauls de Bengala, até a significativos textos contemporâneos, Richards trabalha com os integrantes do grupo ajudando-os a entrar em contato com os aspectos interiores do trabalho. O Focused Research Team está, além disso, explorando as modalidades segundo as quais estes aspectos interiores do trabalho podem facilitar e enriquecer o contato e a experiência humanos. O grupo dedicou-se ao desenvolvimento de detalhadas estruturas performativas e da competência necessária para realizá-las de modo vivo e orgânico.

A equipe chamada Open Program, por outro lado, está em fase de abertura para o exterior e realiza sua proposta, através de três obras: uma festa (Eletric Party), um espetáculo (I am America) e um concerto (Not History Bones - A Poetry Concert).

As linhas de investigação emergentes nestas composiçóes são variadas, mas há uma ligação profunda entre elas que vai do trabalho sobre canto e sobre vibração sonora até a criação e exploração de sequências estruturadas de açóes, através da experimentação de fontes textuais contemporâneas da área norte-americana e da composiçáo de cantos e linhas de açóes a partir da palavra poética viva entendida como instrumento performativo e de contato. Uma linha contígua de investigação concentra-se nos cantos do Sul dos Estados Unidos, no impacto de suas específicas qualidades rítmicas e melódicas e de suas potencialidades como catalisadores de interaçóes. $\mathrm{O}$ resultado é um trabalho de redescoberta da origem dramática e política da criação poética, significativamente interligado a uma investigação das raízes antigas da música contemporânea ocidental (blues, jazz, rock, pop). Tal investigação baseou-se intimamente na necessidade e na possibilidade de um movimento coletivo que visava iluminar 
- através de uma estrutura de açóes reconhecida como evento teatral - aquilo que de essencial esconde-se na nossa natureza de seres sociais e sencientes.

Basicamente se apresenta ao público uma investigação - um laboratório, ter-se-ia dito uma vez - em plena atividade e os conceitos de essência e origem encontram sua razão em um gesto que conecta a existência inteira das pessoas envolvidas em uma prática dramatúrgica, que explicita uma igualmente radical necessidade política. Allen Ginsberg olha para o mundo contemporâneo como Ésquilo fazia em seu tempo, isto é, considerando especialmente a tríade constituída por seres humanos, heróis e instituiçôes, privadas ou públicas, lançando luz sobre a relação de amor-ódio que os liga indissoluvelmente e que caracteriza o momento histórico em que vivemos. Como Ésquilo, seus poemas são um catálogo de nomes e de figuras justapostas, oferecidas à meditação e dos quais se delineia uma genealogia para além das aparências. O conflito entre os homens em suas jornadas e as instituiçóes ocorre no ano novo, a era do Kali Yuga e do hidrogênio, um espaço-tempo que, em seguida, mistura continuamente o início e o fim. Nestas obras, a criatividade entrelaça-se à prece, o lirismo à sensualidade, a evocação a um jargão ácido e divertido, a melancolia ao entusiasmo visionário, o desânimo à profecia, em uma progressão táo irresistível quanto grotes $\mathrm{ca}^{14}$ que a montagem de Biagini valoriza e que desemboca, no caso da festa, em um final aberto a vários possíveis bis que dependem do diálogo com os convidados.

As letras de Allen Ginsberg, a maioria musicada pelos próprios atores do Open Program com surpreendente maestria, assumem os Estados Unidos como ponto de observação e, ao mesmo tempo, como caráter predominante do mundo de hoje. Evocar a atualidade significa questionar-se sobre o mundo em nós e nós no mundo, sobre a nossa escolha ser realizada através da composição de uma obra que entrelaça um trabalho sobre si mesmo (a maturidade individual e profissional dos que trabalharam juntos por dois anos é palpável) e a fundação de uma ecossensibilidade a 360 graus, que vai desde o psíquico até o ambiente natural. O poema America (1956) é, em certo sentido, o fio condutor do espetáculo ${ }^{15}$, ainda que Ginsberg e os atores do Open Program projetem suas cançóes até os anos 1990, com referência a diversos eventos históricos e ao caminho do autor através de várias culturas rumo à maturidade e à velhice. A sua leitura dos Estados Unidos não é mitificadora, mas mítica, no sentido de que, para ex- 
plicar a sua complexidade em termos não banalmente moralistas ou ideológico-maniqueístas e identificar comportamentos construtivos, Ginsberg recorre a figuras de diversas tradiçóes poéticas, antigas e modernas.

O inglês é também a língua de trabalho aqui, mas finalmente tornou-se uma espécie de máscara total que ajuda a descobrir outros modos e vozes fora de si: uma convenção que confere ao ator uma liberdade e um estilo. E não se trata, obviamente, apenas de cançóes ou de cançóes dramatizadas, mas de uma forma dramatúrgica original, se bem que ainda em evolução, que compreende açóes, contatos, composições e inserções de monólogos e diálogos. A tipologia das cenas individuais é bastante variada: frequentemente acontece de um intérprete principal do canto estar acompanhado pelo coro, mas, na realidade, cada ator é uma figura em si, um solista.

Um dos méritos desta criação é o de apresentar a obra poética de Ginsberg como uma Divina Comédia do século XX. A América do título é, na verdade, o mundo atual, é um lugar real e também alegórico no qual cada $e u$ ocupa uma posição diferente. Uma Não Divina Comédia, então, a Visitação de um mundo no qual o apocalipse torna a se repetir continuamente, após duas Guerras Mundiais, as Revoluçóes e o Holocausto, um mundo no qual o Inferno, o Purgatório e o Paraíso estáo confundidos e no qual todos os paradigmas teológicos e as cosmologias do passado naufragaram. Porém, não se trata de uma comédia humana no sentido daquele humanismo burguês que coloca no centro e na fronteira do universo o demasiado humano personagem. É por isso que o caráter visionário de Ginsberg torna crível uma leitura da Estátua da Liberdade como Kali distribuidora de vida e de morte juntas, ou a revelação das relações entre as tragédias do tempo e a grande obra de remoçáo realizada pelos meios de comunicação. Nesta Comédia (irônico errante, commos no karma antes que no dharma) podem-se distinguir alguns grandes temas propostos pelo autor, como a funçáo da poesia e aquela do sexo, as variaçóes locais da política ou as potencialidades traídas da revolução, mas também temos que lidar com o seu fatal entrelaçamento nos acontecimentos cotidianos de Cada Um, fora de qualquer paradigma moral. Talvez náo se trate de uma analogia consciente por parte do poeta, que Jack Kerouac, em Pé na estrada (On the Road), chame-se Carlo Marxx ${ }^{16}$, mas de uma correspondência objetiva que 
emana da ambição e da tentativa experimental de se representar o mundo desconhecido de hoje.

A obra poética de Ginsberg, na verdade, não pretende desenhar ou julgar a história do mundo, mas traça uma outra estrada: busca transformá-lo, ao mundo, mas cantando ("Not history bones but vocal tones" (Ginsberg, 1972, p. 87) é um verso de $A$ prophecy, um poemeto ginsberguiano escrito em pleno 1968). Estruturado como outros grandes poemas da história - da Bíblia à Ilíada, ao Mahabharata ou à saga tibetana de Gesar, passando por Dante até os singulares versos de Villon ou ao estilo entre o aforismo e a gravação ao vivo de Karl Kraus -, a saber, com episódios autônomos que, aproximados por analogia ou por contraste, indicam o destino de uma mesma gente em movimento, o texto proposto é resultado de um escutar contínuo do poeta pelas ruas e pelas casas, daquela particular atenção dispensada ao mundo que consistiu toda a sua vida. A obra de Ginsberg nasce de um fundo de música e canto (e, aqui, de descobertas da comunicação) e encontra seu pleno significado na encarnação desses menestréis errantes do século XXI.

O diretor, aqui, é um ator que, pela primeira vez, escolheu não entrar em cena e sacrificou-se para potencializar ao máximo a criatividade dos seus colegas e suas consequentes responsabilidades. Os atores não encarnam personagens, mas diferentes tipos humanos nos quais cada um encontra sua própria voz, fisicalidade e imagem, figuras que se colocam em jogo a cada sequência, com uma contínua troca de funçóes. Mas o trabalho de cada um caracteriza-se por um mesmo grau de precisão, quer esteja em primeiro plano ou ao fundo. Marina Gregory, por exemplo, por sua história e suas características, possui uma relaçáo particular com o tema e o material dos espetáculos e terminou por assumir uma identificaçáo com a América, que constitui o eixo central da ação. A sua é uma América prismática, que pode ser dura e angular ou transformar-se em uma dolorosa Madona; sua passagem pelo material verbal ginsberguiano retoma um aspecto inquietante, impiedoso, e também manifesta a vitalidade compassiva que, ao menos como possibilidade, caracteriza igualmente a América multiétnica.

Tudo nasce de um imponente trabalho coletivo, mas se concretiza no âmbito da poética de Biagini, ou em nome de uma vertiginosa mistura de embriaguez e sensualidade (festiva, mas também 
contraditória e fatal), de ironia, de consciência lúcida e também de abandono. Aqui os motivos que levaram Grotowski a deixar o teatro dos espetáculos são, de certa maneira, resolvidos em um espetáculo leve, que se coloca a uma distância sideral da tendência generalizada em considerar Grotowski como o bardo de uma animação teatralespiritual que oscila entre vitalismo e melancolia. Biagini não esquece que a ênfase do mestre sempre recaiu sobre a arte, e, por isso, coerente com o seu espírito, assume para si as próprias responsabilidades. E a verticalidade, nesse jogo dionisíaco e de comediantes, consiste em uma maneira diferente de pregar laicamente: uma obra é atual náo porque se refere à atualidade, mas porque responde a ela e, respondendo-lhe, indica algumas possibilidades de ultrapassá-la. O eu de Allen Ginsberg, autor de uma obra intraduzível e irrepresentável, como toda poesia que inventa uma língua, revive na individualidade de cada um dos atores, poetas por sua vez, e de cada um dos espectadores, ao menos daqueles que almejam um teatro à altura de seu tempo, que ilumine o presente e pressuponha uma resistência e uma rebeliáo que também contenham a celebração da vida e a busca da felicidade. 


\section{Notas}

${ }^{1}$ A presente contribuição retoma partes de algumas intervenções precedentes sobre Jerzy Grotowski e o Workcenter para tentar estabelecer os aspectos mais significativos de um legado e de uma atividade contínua que Ferruccio Marotti sempre levaram em consideração, diferentemente da oscilante cultura teatral italiana.

${ }^{2}$ Discurso pronunciado na televisão polonesa em 15 de janeiro de 2009 e retomado pelo "la Repubblica" em 6 de março de 2009.

3 "Fazíamos o nosso trabalho não para, mas, contra alguma coisa. E não somente no sentido político - que teria sido superficial - mas, no sentido da existência humana. $\mathrm{O}$ que é importante na vida? O que é, pelo contrário, somente merda? O que significa trabalhar e talvez morrer? O que se pode realmente aceitar e o que se deve recusar? Tudo isso implicava um preço terrível a ser pago" (Grotowski está falando dos primórdios do Teatr Laboratorium. Cfr. Anatolij Vassiliev, cronaca del quattordici, em Opere e Sentieri, III, Testimonianze e riflessioni sull'arte come veicolo, organizado por A. Attisani e M. Biagini, Bulzoni, Roma, 2008, p. 75-96).

${ }^{4}$ A Ferruccio Marotti deve-se, entre outras coisas, o empenho para a edição italiana de Per un teatro povero (Roma: Bulzoni, 1970) e muitas outras coisas, como a recuperaçáo do filme sobre o Principe constante, dois símbolos que dizem como a sua produtividade fertilíssima se realizou sobre a marca da discrição e driblando a soberba de autor que quer passar à história imprimindo a marca da própria opinião sobre os assuntos de sua especialização. De qualquer modo, a Itália é o país que, mais do que qualquer outro, acolheu generosamente Grotowski, e quem na Itália aproxima-se hoje do mestre tem sorte, porque entre aqueles que lhe estiveram próximos estão pessoas como Carla Pollastrelli e Mario Biagini, bem como a realidade do Workcenter of Jerzy Grotowski and Thomas Richards e da Fundação Pontedera Teatro, sem os quais seria inimaginável o atual e impressionante trabalho de restauração filológica e de traduçáo, o que, frequentemente, nos permite ler aqueles textos antes dos outros. No restante do mundo, este trabalho procede com lentidão e muitas ambiguidades (sobre este cfr. eventualmente A. Attisani, "Un programma di lavoro", em Smisurato cantabile. Note sul lavoro del teatro dopo Jerzy Grotowski, Edizioni di pagina, Bari 2009. No mesmo livro são indicadas diversas publicaçóes recentes sobre Grotowski e o Workcenter).

${ }^{5}$ Cfr. J. Grotowski, "Esercizi”, em Il Teatr Laboratorium de Jerzy Grotowski 1959-1969, Textos e Materiais de Jerzy Grotowski e Ludwig Flaszen, com um escrito de Eugenio Barba, organizado por L. Flaszen, C. Pollastrelli e R. Molinari, Fondazione Pontedera Teatro, Pontedera 2001 (após, La casa Usher, Florença 2007).

${ }^{6}$ Cfr. C. Sini, Le arti dinamiche. Filosofia e pedagogia - Figure dell'enciclopedia filosofica, sexto livro, Jaca Book, Milão 2004.

${ }^{7}$ L. Flaszen, Intorno al 1956. Rivolta e conformismo nella vita culturale polacca, tradução e notas de Eugenio Barba. "Teatro e storia”, 28, 2007, p. 15-56.

${ }^{8}$ Cfr. J. Grotowski, Performer, em Opere e sentieri, II: Jersey Grotowski. Textos 1968-1998, organizado por Attisani e M. Biagini, Bulzoni, Roma 2007. 
${ }^{9}$ Refiro-me também aos filmes da última fase, como Dowstairs Action de Mercedes Gregory (1989), Action in Aya Irini (2003), Dies Ira (2006) e a outras montagens realizadas e exibidas pelo Workcenter.

${ }^{10} \mathrm{~J}$. Grotowski, "Dalla compagnia teatrale all'arte come veicolo", em Opere e sentieri, II (2007).

${ }^{11}$ Cfr. L. Flaszen, Da mistero a mistero, em Il Teatr Laboratorium di Jerzy Grotowski 19591969.

${ }^{12}$ Sobre este tema cfr., eventualmente, de quem escreve, Actoris Studium, Album \#1, Processo e composizione nella recitazione da Stanislavskij a Grotowski e oltre, Edizioni dell'Orso, Alessandria, 2009.

${ }^{13}$ René Daumal, Jaques-Dalcroze, éducateur, (1934), em L'evidence absurde, essais et notes, I (1926-1934), édition établie par Claudio Rugafiori, Gallimard, Paris 1972, p. 270-275.

${ }_{14}$ Biagini amplifica a ressonância grotesca já presente em Ginsberg. Se para o escritor americano trata-se de uma sensibilidade que se refere mais ou menos explicitamente ao grotesco de Rabelais, "atualizado” por Mikhail Bakhtin, para Biagini é necessário pensar sobre a tradição teatral que vai de Meyerhold a Grotowski e outros.

${ }^{15}$ America fala de um jovem que reflete sobre o próprio ser cidadão dos Estados Unidos, que procura as palavras para manifestar a raiva que a política daquele país e suas remoçóes assustadoras nele suscitam, e que, ao mesmo tempo, o ama como lugar para viver, terminando por deliberar que aceita fazer parte dele, embora recusando "se alistar no exército ou girar tornos em fábricas de peças de precisão" e dedicando-se, ao invés disso, à obra com seus frágeis braços.

${ }^{16}$ Um dos estímulos mais interessantes desta operação é o de voltar a atenção novamente à beat generation e à obra de Jack Kerouac, um autor a ser redescoberto, seja sob o plano dos conteúdos, seja pela estratégia poética. Por exemplo, Pé na estrada (On the road) é uma evidente (se bem que ignorada pela maioria) atualização do Hino da Pérola gnóstico, com sua viagem de leste a oeste e retorno em busca da pérola, descobrindo que o objetivo é a jornada e o variado destino dos "irmãos" que realizam a viagem, etc. Uma releitura da beat generation também implicará em uma distinção entre resultados elevados e buscas substancialmente fracassadas no plano artístico (a poesia de Ginsberg e apenas alguns romances de Kerouac situam-se no primeiro caso; já a prosa ginsberguiana e a produção poética de Kerouac, por exemplo, pertencem ao segundo caso, sendo consideradas mais como registros de intençóes e hipóteses críticas) e uma atenção diferente à parte ensaísticodiscursiva.

\section{Referências}

ATTISANI, Antonio. Actoris Studium, Album \#1, Processo e composizione nella recitazione da Stanislavskij a Grotowski e oltre. Alessandria: Edizioni dell’Orso, 2009.

ATTISANI, Antonio. Smisurato cantabile. Note sul lavoro del teatro dopo Jerzy Grotowski. Bari: Edizioni di pagina, 2009. 
BROOK, Peter. Prefácio. In: GROTOWSKI, Jerzy. Per un Teatro Povero. Roma: Bulzoni, 1970. P. 11-12.

DAUMAL, René. Jaques-Dalcroze, éducateur. In: RUGAFIORI, Claudio; DAUMAL, René (Org.). L'Evidence Absurde, Essais et Notes, I (1926-1934). Paris: Gallimard, 1972. P. 270-275.

FLASZEN, Ludwik. Intorno al 1956. Rivolta e conformismo nella vita culturale polacca. Teatro e Storia, Roma, v. 28, p. 15-56, 2007.

FLASZEN, Ludwik. Da mistero a mistero. In: FLASZEN, Ludwik; POLLASTRELLI, Carla; MOLINARI, Renata (Org.). Il Teatr Laboratorium de Jerzy Grotowski 19591969. Pontedera: Fondazione Pontedera Teatro, 2001.

GINSBERG, Allen. The Fall of America: poems of these states, 1965-1971. San Francisco: City Lights Books, 1972.

GROTOWSKI, Jerzy. Tu es le Fils de Quelqu'un. In: ATTISANI, Antonio; BIAGINI, Mario (Org.). Opere e Sentieri, II: Jerzy Grotowski. Testi 1968-1998. Roma: Bulzoni, 2007. P. 73-81.

GROTOWSKI, Jerzy. Esercizi. In: FLASZEN, Ludwik; POLLASTRELLI, Carla; MOLINARI, Renata (Org.). Il Teatr Laboratorium de Jerzy Grotowski 1959-1969. Pontedera: Fondazione Pontedera Teatro, 2001. P. 48.

SINI, Carlo. Le Arti Dinamiche. Filosofia e Pedagogia - Figure dell'Enciclopedia Filosofica, sexto livro. Miláo: Jaca Book, 2004.

VASSILIEV, Anatolij. Cronaca del Quattordici. In: ATTISANI, Antonio; BIAGINI, Mario (Org.). Opere e Sentieri, III: testimonianze e riflessioni sull'arte come veicolo. Roma: Bulzoni, 2008. P. 75-96.

Antonio Attisani foi ator, crítico teatral e diretor do Festival Internacional de Santarcangelo, antes de se tornar, em 1992, professor de História do Teatro. Foi professor na Università degli Studi Ca' Foscari, em Veneza. Atualmente, é professor na Università di Torino.

E-mail: antonio.attisani@unito.it

Traduzido do original em italiano por Letícia de Abreu Rodrigues e Jane Diogo Trein sob a supervisão de Cláudia Mendonça Scheeren (Universidade Federal do Rio Grande do Sul). Revisão técnica de Tatiana Motta Lima (Universidade Federal do Estado do Rio de Janeiro).

Recebido em 29 de setembro de 2012 Aprovado em 27 de dezembro de 2012 